\title{
Nanomaterials for Airborne Virus Inactivation: A Short Review
}

\author{
Rong $\mathrm{Li}^{1,2,3} \cdot$ Long Cui ${ }^{1,2} \cdot$ Meijuan Chen ${ }^{4} \cdot$ Yu Huang ${ }^{1,2}$
}

Received: 16 July 2020 / Revised: 10 October 2020 / Accepted: 14 October 2020 / Published online: 30 October 2020

(c) Institute of Earth Environment, Chinese Academy Sciences 2020

\begin{abstract}
The coronavirus disease 2019 (COVID-19) that broke out at the end of 2019 spread rapidly around the world, causing a large number of deaths and serious economic losses. Previous studies showed that aerosol transmission is one of the main pathways for the spread of COVID-19, Therefore, effective control measures are urgently needed to contain the epidemic. Nanomaterials have broad-spectrum antiviral capabilities, and their inactivation for viruses in the air has been extensively studied. This review discusses antiviral nanomaterials such as metal nanomaterials, metal oxide-based nano-photocatalysts, and nonmetallic nanomaterials; summarizes their structure and chemical properties, the efficiency of inactivating viruses, the mechanism of inactivating viruses, and the application of virus purification in the air. This review provides insights on the development and application of antiviral nanomaterials, which can help control the aerosol transmission of viruses.
\end{abstract}

Keywords COVID-19 $\cdot$ Aerosol transmission $\cdot$ Nanomaterials $\cdot$ Antiviral

\section{Introduction}

The coronavirus disease 2019 (COVID-19) that broke out at the end of 2019 is still a pandemic across the world, which has caused great damage to human health and economic development. Curbing the spread of COVID-19 needs to be considered from three aspects: controlling the source of infection, cutting off the transmission pathways, and protecting susceptible individuals (Wilson and Zumla 2019). Studies have shown that one of the main transmission pathways of COVID-19 is the droplets produced by patients which then form biological aerosols (Ge et al. 2020). This pathway has also been verified in the spread of other viruses such

Yu Huang

huangyu@ieecas.cn

1 Key Laboratory of Aerosol Chemistry and Physics, State Key Laboratory of Loess and Quaternary Geology (SKLLQG), Institute of Earth Environment, Chinese Academy of Sciences, Xi' an 710061, People's Republic of China

2 CAS Center for Excellence in Quaternary Science and Global Change, Xi'an 710061, People's Republic of China

3 University of Chinese Academy of Sciences, Beijing 100049, People's Republic of China

4 School of Human Settlements and Civil Engineering, Xi' an Jiaotong University, Xi' an 710049,

People's Republic of China as influenza viruses (Lindsley et al. 2016), SARS viruses (Tang et al. 2006), etc. Van Doremalen et al. (2020). found that COVID-19 can survive for more than $3 \mathrm{~h}$ in aerosols. Besides, some researches and field study reports show that viral RNA from COVID-19 can be detected in the air (Liu et al. 2020; Ong et al. 2020). Therefore, controlling the spread of biological aerosols is the most effective way to inhibit the spread of viruses.

Currently, commonly used measures for protection against airborne viruses include wearing protective clothing and mask (Brienen et al. 2010), increasing indoor ventilation (Sze-To et al. 2014), and chemical disinfecting (Brienen et al. 2010). However, there are several limitations: wearing protective clothing and mask for a long period can be uncomfortable for human; ventilation is not suitable for all indoor environments; and cumbersome chemical disinfection does not have long-term effectiveness. Therefore, more effective measures are in need to continuously and efficiently inactivate airborne viruses with limited effect on the daily life of the public. Current researches have utilized microwave, ozone, ultraviolet, plasma, and filtration technologies to develop indoor purification devices that are able to inactivate viruses in aerosols. The efficiency of microwave disinfection depends on the combined effects of microwave thermal, field and quantum effects (Brondani and Siqueira 2018). Wu and Yao (2014) found that under $700 \mathrm{~W}$ of microwave radiation, $90 \%$ of the airborne MS2 virus was 
inactivated within $2 \mathrm{~min}$. Ozone takes effect on the polypeptide chain of the viral capsid protein and damages the nucleic acid (Murray et al. 2008). Hudson et al. (2007) designed a portable ozone generator module, which is capable of generating $25 \mathrm{ppm}$ ozone with an inactivation capacity of more than $99.9 \%$ for the sample virus. The strong absorption of high-energy ultraviolet light by viral proteins and nucleic acids would destroy the viruses (Wigginton and Kohn 2012) and upper-room ultraviolet germicidal irradiation (UVGI) system is an effective way to control the transmission of viruses by aerosols (Linnes et al. 2014). The mechanisms for inactivating the viruses with low-temperature plasma include the strong oxidation of reactive oxygen species (ROS), the bombardment of high-kinetic energy electrons on the virus shell, and the inhibitory effect of ultraviolet light on nucleic acid synthesis (Pradeep and Chulkyoon 2016). Xia et al. (2019) designed a dielectric barrier discharge non-thermal plasma packed bed reactor to process the gas flow inoculated with virus aerosol, which can reduce MS2 virus by $2.3 \log$. In terms of the diffusion effect of the nanosize virus particles, high-efficiency filtration is effective to remove viruses in ambient air (Azimi and Stephens 2013). Malaithao et al. (2009) found that high-efficiency particulate air (HEPA) filters can remove $99 \%$ of the airborne T7 virus with a particle size of $40 \mathrm{~nm}$.

Virus possesses a size in the nanoscale range and its protein shell is hard. Even if the shell protein is destroyed, it may not be completely fatal. On the other hand, it can be inactivated completely by destroying the nucleic acid (Zhang et al. 2019a). However, it is reported that the virus may be resistant to the treatment by the aforementioned methods (Camara et al. 2017; Carratala et al. 2017). In recent years, studies have confirmed the inactivation effects of nanomaterials on various viruses. Nanomaterials refer to materials with dimensions in the nanoscale range $(1-100 \mathrm{~nm})$. Due to large specific surface area, rich surface atom, and high surface energy, nanomaterials exhibit unique optical, thermal, mechanical, electrical, and chemical properties (McNeil 2009). Nanomaterials can inactivate viruses through physical contact, the generation of ROS, catalytic oxidation, photothermal effects, and metal ion release. Moreover, nanomaterials can be combined with other measures to enhance antiviral performance. Therefore, it is very promising to develop anti-viral nanomaterials and apply them to air purifier filters, building ventilation system, anti-viral fabrics, and anti-viral spraying agents, which assists to control the spread of viruses through aerosols.

In this review, antiviral nanomaterials have been categorized into metal nanomaterials, metal oxide-based nano-photocatalysts, and nonmetallic nanomaterials. Their efficiency and mechanism of inactivating viruses are summarized. In addition, some purification devices aiming for inactivating the airborne viruses are listed as well. We hope that this review will provide inspiration for the development of antiviral nanomaterials to control the aerosol transmission of viruses.

\section{Metal Nanomaterials}

Numerous studies have shown that metal nanoparticles such as Ag (Lara et al. 2010), Cu (Armstrong et al. 2017), $\mathrm{Au}$ (Broglie et al. 2015), Fe (Kim et al. 2011), etc., exhibit broad-spectrum antiviral capabilities, making them widely used in medicines and the disinfection of water or air. Galdiero et al. (2011) suggested that the effect of metal nanoparticles on virus inactivation may play a role before and after viruses enter host cells (Fig. 1a). First of all, the virus can be adsorbed on the metal surface, and the glycoproteins of virus interact with the metal particles and become inactive. Secondly, metal nanoparticles may enter cells and interact with viral nucleic acids to exert their antiviral capability. (a)

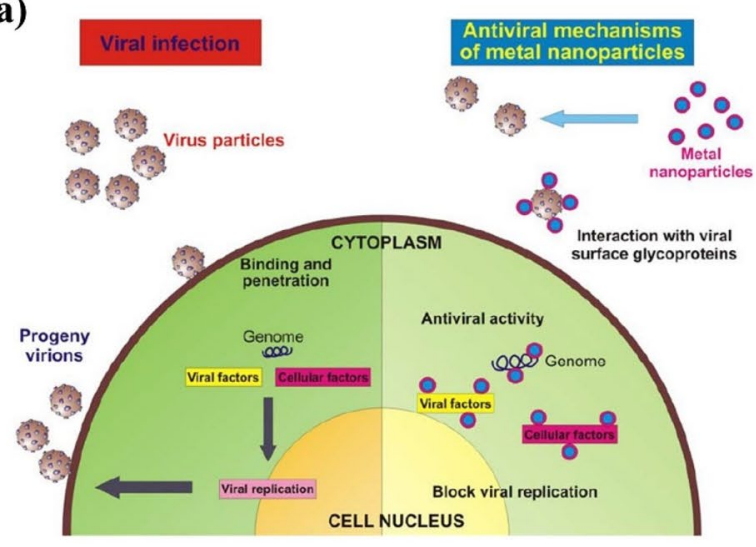

(b)

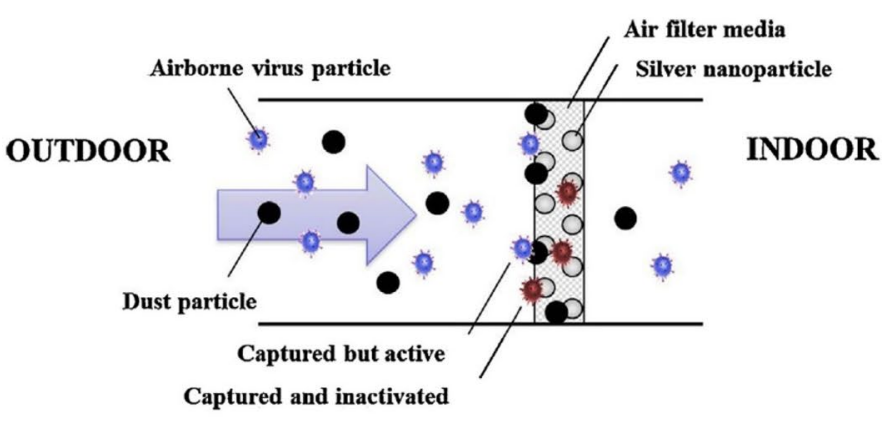

Fig. 1 a Schematic model of virus infection in eukaryotic cells and antiviral mechanism of metal nanoparticles (Galdiero et al. 2011). b Schematic diagram of a nano Ag-loaded filter to remove viruses in the air (Joe et al. 2016) 
Nano Ag has been proved to be one of the most widely used antibacterial materials due to its high specific surface area and unique chemical and physical properties (Marambio-Jones and Hoek 2010). Its antiviral properties have also been extensively studied. According to the literature, the anti-viral mechanism of nano Ag is as follows: (1) Nano Ag has a strong adsorption effect on the virus and can interact with the viral envelope or surface protein, affect the interaction between the virus and the cell receptor, thereby preventing the virus from invading the cell (Xiang et al. 2011). This adsorption effect may be related to the size effect of nano Ag (Gaikwad et al. 2013). (2) Nano Ag combined with virus can release $\mathrm{Ag}$ ions, which react with viral proteins and inactivate them; or react with viral nucleic acids to prevent viruses from replicating (Hu et al. 2020). (3) The surface of nano-Ag can activate oxygen to produce ROS (Yan et al. 2005), which oxidizes virus and seriously damages its structure (Belanger et al. 2011).

Lu et al. (2008) synthesized Ag nanoparticles with an average particle size of $10 \mathrm{~nm}$, similar to that of hepatitis $\mathrm{B}$ virus (HBV). This study found that nano Ag can directly interact with $\mathrm{HBV}$ virus particles. The strong binding force between $\mathrm{Ag}$ and $\mathrm{HBV}$ virus hindered the transcription of viral genetic material and the formation of new DNA. Joe et al. (2014) loaded nano-Ag on the $\mathrm{SiO}_{2}$ surface, and the obtained $\mathrm{SiO}_{2}-\mathrm{Ag}(\mathrm{SA})$ nano-particles were applied on the medium air filter. Under continuous airflow, this study evaluated the pressure drop, filtration efficiency, and anti-virus (MS2) capacity of SA filters. It was found that the filtration efficiency and pressure drop increased with the decrease of the medium flow rate and the increase of the coating amount of SA particles. The increasing coating amount of SA particles resulted in the enhanced antiviral efficiency and finally $99.9 \%$ of the virus particles lost their infectivity. However, with the increase of the virus deposition time, the anti-virus efficiency decreased. In the actual environment, viruses may be adsorbed on airborne particulate matter, and the dust trapped on the filter may affect the anti-virus capacity of the filter. Therefore, this group (Joe et al. 2016) then used the dust load test to study the pressure drop, filtration efficiency and antiviral ability of the filter on MS2 virus particles (Fig. 1b), and found that the filtration efficiency and pressure drop increased with the increase of dust concentration. The decreased antiviral capacity may be due to the fact that dust particles hindered direct contact between $\mathrm{Ag}$ nanoparticles and virus particles.

Nano $\mathrm{Cu}$, less expensive than $\mathrm{Ag}$, also has broad-spectrum antiviral activity. Its antiviral mechanism remains unclear. One theory is that the negatively charged $\mathrm{Cu}$ surface adsorbs viruses through electrostatic action (Szekeres et al. 2018), and $\mathrm{Cu}$ ions can catalyze the formation of ROS (Pandey et al. 2019) to oxidize viruses. Han et al. (2005) reported that two metal catalysts, $\mathrm{Ag} / \mathrm{Al}_{2} \mathrm{O}_{3}$ and $\mathrm{Cu} / \mathrm{Al}_{2} \mathrm{O}_{3}$, blocked the transmission of SARS and other respiratory infections. In this study, these metal catalysts were pressed into wafers and they could destroy the replication and reproduction ability of SARS coronavirus, baculovirus and $E$. coli on the surface. Interestingly, only when the virus on the catalyst surface was in contact with the air, metal catalysts possessed the ability of inactivation. Horie et al. (2008) reported that $\mathrm{Cu}^{2+}$ at low concentration could inhibit H9N2 virus infection in MDCK cells. Electron microscopy analysis showed that $\mathrm{Cu}^{2+}$-treated H9N2 virus had abnormal morphology. Fujimori et al. (2012) studied the antiviral activity of nano CuI particles with an average particle size of $160 \mathrm{~nm}$ and confirmed that nano $\mathrm{CuI}$ particles can generate $\cdot \mathrm{OH}$ radicals in water, thus inactivating H1N1 influenza virus. Shionoiri et al. (2012) studied the effects of $\mathrm{CuI}$ nanoparticles on feline calicivirus (FCV) (as a substitute for human norovirus) infecting Crandell-Rees fetal kidney cells (CRFK). Under the effect of CuI nanoparticles, the infectivity of FCV on CRFK cells decreased by $7 \log$. Electron spin resonance and nano-liquid chromatography-mass spectrometry proved that the high antiviral capacity of $\mathrm{CuI}$ nanoparticles was attributed to the generation of ROS caused by $\mathrm{Cu}^{+}$, which oxidize amino acids in viral capsid protein. Electrostatic adsorption is one of the antiviral mechanisms of nanoparticles (Darkwah and Ao 2018). To improve the virus-absorbing ability of copper nanoparticles, Mazurkow et al. (2020) used plate-shaped alumina particles to support $\mathrm{Cu}$ (oxide) nanoparticles, and evaluated the effect of $\mathrm{Cu}$ oxidation state on MS2 virus removal capacity. The results showed that $\mathrm{Cu}$ (I) oxide and metallic copper were capable of removing $99.9 \%$ of MS2 virus. However, there was almost no virus removal in the presence of $\mathrm{Cu}$ (II) oxide. The zeta potential measurement found that the virus inactivation energy can be attributed to the positive surface charge characteristics of $\mathrm{Cu}_{2} \mathrm{O}$ and $\mathrm{Cu}$, respectively. Positive surface charge was favorable for the adsorption of negatively charged MS2 virus.

\section{Metal Oxide-Based Nano-Photocatalysts}

When the incident light energy is greater than or equal to the forbidden bandwidth of the metal oxide semiconductor material, the valence band electrons of the semiconductor are excited to transit to the conduction band, and at the same time, corresponding holes are generated in the valence band to form electron-hole pairs (Pant and Park 2019). Part of the photogenerated electrons and holes migrate to the surface of the material under the effect of the internal electric field (Gupta and Modak 2020). The surface of the catalyst generates $\cdot \mathrm{OH}$ radicals, $\cdot \mathrm{O}^{2-} \mathrm{rad}$ icals and other ROS (Ahmed and Haider 2018), which oxidizes adsorbed viruses, causing damage to their proteins (Badireddy et al. 2012) and genes (Ishiguro et al. 
2011). Since photocatalysis has the advantages of broad anti-virus range, long-lasting and high efficiency (Zhang et al. 2019a), it can be an alternative disinfection strategy to improve virus disinfection performance. Currently, popular antiviral metal oxide photocatalytic materials are $\mathrm{TiO}_{2}$ (Yamaguchi et al. 2016), $\mathrm{ZnO}$ (Bogdan et al. 2015), $\mathrm{Fe}_{2} \mathrm{O}_{3}$ (Giannakis et al. 2017), $\mathrm{WO}_{3}$ (Takehara et al. 2010), etc. As shown in Fig. 2a, in addition to generating virusoxidizing ROS through photocatalysis, photocatalysts can also cause physical damage to the structure of the virus with the sharp edges on the nanostructure (Hu et al. 2012), while the loaded metal ions can be toxic to the virus (Liga et al. 2011). According to Li's research (Li et al. 2016b), a typical process of photocatalytic inactivation of viruses can be divided into the following three steps: virus shape distortion, virus coat protein oxidation, and virus internal gene leakage or damage.

$\mathrm{TiO}_{2}$ is currently the most commonly used antiviral metal oxide photocatalyst. It has the advantages of broad-spectrum anti-virus performance, stable structure, non-toxic to humans, and low cost (Laxma Reddy et al. 2017). As early as 1994, Sjogren and Sierka (1994) studied the inactivation effect of $\mathrm{TiO}_{2}$ photocatalysis on MS2 virus. Subsequent studies have focused on the inactivation of viruses by photocatalysis in water, and in recent years researchers have shifted their focus to the application on inactivating airborne viruses. Zan et al. (2007) studied for the first time the photocatalytic effect of nano- $\mathrm{TiO}_{2}$ particles and $\mathrm{TiO}_{2}$-coated ceramic plates on HBV. The results demonstrated that both $\mathrm{TiO}_{2}$ suspension and $\mathrm{TiO}_{2}$ coated ceramic plates were capable of destroying most $\mathrm{HBV}$ antigens ( $\mathrm{HBsAg}$ ) under weak ultraviolet light, weak sunlight or indoor sunlight. Further research by Xu et al. (2007) found that the killing effect of $\mathrm{TiO}_{2}$ on HBV was mainly attributed to the destruction of HBsAg, RNA and casein by photocatalytic oxidation.

As for the application of $\mathrm{TiO}_{2}$ in virus disinfection, one limitation is the wide bandgap of $\mathrm{TiO}_{2}(3.2 \mathrm{eV}$ for anatase), and thus only $4 \%$ of solar energy can be utilized for the photocatalytic sterilization of the material (Daghrir et al. 2013); another limitation is that the high electron-hole recombination rate of $\mathrm{TiO}_{2}$ reduces its photocatalytic efficiency (Foster et al. 2011). Therefore, researchers have adopted many modification measures to improve the virus-inactivation capacity of $\mathrm{TiO}_{2}$ under visible light (Dong et al. 2015). Loading nano-metal particles on $\mathrm{TiO}_{2}$ catalyst is an effective way to improve the photocatalytic efficiency (Gupta and Tripathi 2011). Nanoparticles such as Pd (Li et al. 2008), Ag (Bogdanov et al. 2017), $\mathrm{Cu}$ (Zheng et al. 2017), Mn (Venieri et al. 2015) and their oxides are commonly used to enhance the antiviral ability of $\mathrm{TiO}_{2}$. By introducing these components with lower external bandgap to combine with $\mathrm{TiO}_{2}$, the separation of electron-hole pairs can be promoted, and metal can also be built as active sites on the surface of $\mathrm{TiO}_{2}$. (a)

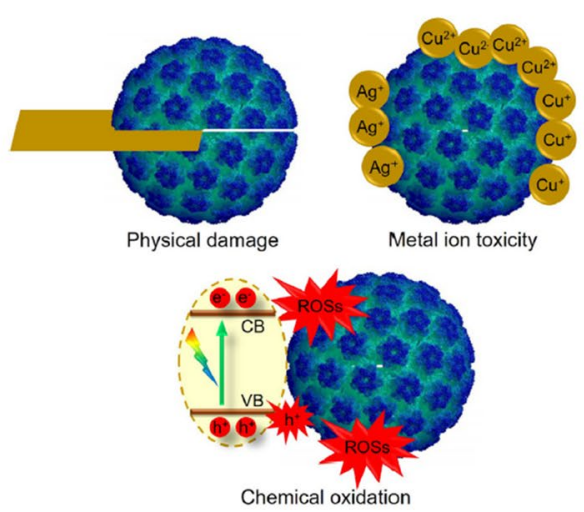

(b)

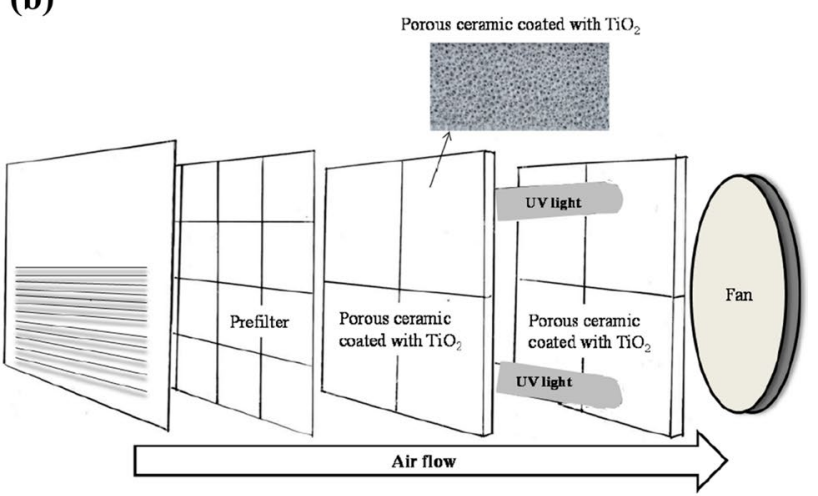

(c)

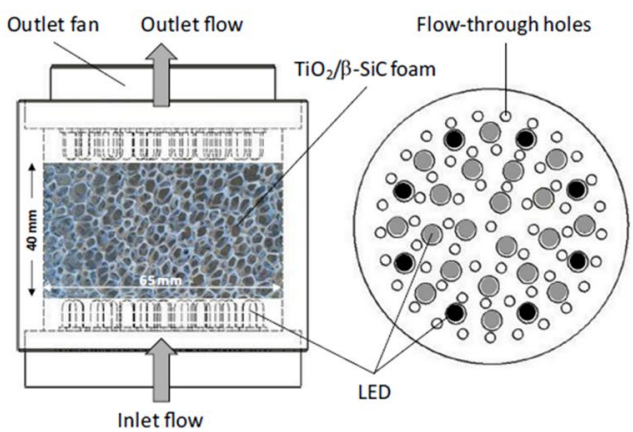

Fig. 2 a The major mechanism of nano photocatalysts for virus inactivation (Zhang et al. 2019a). b The schematic structure of the air cleaner with $\mathrm{TiO}_{2}$ coating porous ceramic substrate (Daikoku et al. 2015). c The schematic structure of the photocatalytic reactor with $\mathrm{TiO}_{2} / \beta$-SiC foam (Doss et al. 2018)

Kozlova et al. (2010) loaded acidic $\mathrm{TiO}_{2}$ and Pt-modified acidic $\mathrm{TiO}_{2}$ on glass plates, respectively, and studied their inactivation mechanics against influenza A virus (H3N2) in aerosols under the light. After 30 min of UVA illumination, the inactivation rate of $\mathrm{Pt} / \mathrm{TiO}_{2}$ to $\mathrm{H} 3 \mathrm{~N} 2$ was $99.8 \%$, which was much higher than that of $\mathrm{TiO}_{2}$ only. This can be attributed to the fact that Pt enhances the efficiency of virus adsorption and semiconductor charge separation. 
Moongraksathum et al. (2019) synthesized silver-deposited titanium dioxide $\left(\mathrm{Ag} / \mathrm{TiO}_{2}\right)$ nanocomposite sol and coated it on a glass substrate to form a thin film. It was found that the sample had almost 100\% antiviral effect on H1N1 virus and enterovirus 71 under UVC or visible light irradiation. The particle size of silver on $\mathrm{TiO}_{2}$ was only $1-3 \mathrm{~nm}$, and mostly in the metallic state. Compared with pure $\mathrm{TiO}_{2}$, the photocatalytic activity of $\mathrm{Ag} / \mathrm{TiO}_{2}$ was significantly increased. $\mathrm{Ag}$ loading can capture excited electrons to inhibit the recombination of electrons and holes in $\mathrm{TiO}_{2}$, increase the performance of adsorbing viruses, and release $\mathrm{Ag}^{+}$to inactivate viruses. Zheng et al. (2018) prepared a one-dimensional $\mathrm{Cu}-\mathrm{TiO}_{2}$ nanofiber, which could completely inactivate bacteriophage $\mathrm{f} 2$ under visible light irradiation. This catalytic performance was attributed to the fact that $\mathrm{Cu}^{2+}$ replaces part of the positions of $\mathrm{Ti}^{4+}$ in the $\mathrm{TiO}_{2}$ lattice, forming an impurity level lower than the conduction band of $\mathrm{TiO}_{2}$, which enables the nanofibers to achieve photocatalytic activity under visible light.

For viruses in bioaerosol, some studies have designed air purification devices to inactivate them. Wang (2013) extracted active ingredients with antiviral and antibacterial functions from traditional Chinese medicines, and prepared them as uniform micro-capsules with slow-release properties. The microcapsule, nano $\mathrm{ZnO}$ and $\mathrm{TiO}_{2}$ were coated on polypropylene perforated felt to form a composite air filter with anti-viral performance, and its inactivation rate for influenza A virus was 100\%. Daikoku et al. (2015) synthesized a porous ceramic substrate with nano- $\mathrm{TiO}_{2}$ coated on the wet surface of porous ceramics by fixing fine $\mathrm{TiO}_{2}$ nanoparticles under negative pressure for an air cleaner (Fig. 2b). This study used ultraviolet light as a light source to test the inactivation energy for influenza viruses in aerosol in a 754-L cabin, and found that influenza viruses could be inactivated in $5 \mathrm{~min}$. A controlled experiment without UV light showed that the virus lost its infectivity after $30 \mathrm{~min}$. In addition, by washing the surface of the substrate with deionized water, the porous ceramic substrate coated with nano- $\mathrm{TiO}_{2}$ can be reused.

In the photocatalytic purifier, the choice of different light sources has a great effect on the performance of photocatalysts. Kim and Jang (2018) developed a photocatalytic reactor containing a $\mathrm{Pd}-\mathrm{TiO}_{2}$ catalytic framework. This study used VUV light sources that could easily break most of the chemical bonds and then produce ROS and ozone. It was able to inactivate $90 \%$ MS2 virus passing through the reactor within the irradiation time of $0.009 \mathrm{~s}$. In addition, for the by-product ozone of the VUV light source, the $\mathrm{Pd}-\mathrm{TiO}_{2}$ catalyst could also reduce it to below the emission limit. Doss et al. (2018) used a $392 \mathrm{~nm}$ light-emitting diode (LED) as a light source to irradiate $\mathrm{TiO}_{2} / \beta-\mathrm{SiC}$ solid foam material to build a small flow structure photocatalytic device for air purification (Fig. 2c). $\mathrm{TiO}_{2} / \beta$-SiC solid foam material was made of nano $\mathrm{TiO}_{2}$ supported on $\beta$-SiC foam with medium surface area and large cell size. The study showed that the efficiency of inactivating bacteriophage $\mathrm{T} 2$ in the air was determined by the combined effect of the photocatalytic activity of $\mathrm{TiO}_{2} / \beta-\mathrm{SiC}$ solid foam and passive filtering effect. A high efficiency of photocatalytic filtration of viruses was observed with 56 light-emitting diodes, and 3 log decrease was reached within a 60-min running time.

In addition to applying nano $\mathrm{TiO}_{2}$ to the purifier as an anti-viral filter material, the nano $\mathrm{TiO}_{2}$ sol can be coated in hospitals and other environments prone to high concentrations of viruses. Furthermore, nano $\mathrm{TiO}_{2}$ can also be used as a spray to quickly eliminate viruses. Cui et al. (2010) used a one-step method to prepare a $1.6 \%$ neutral anatase nano- $\mathrm{TiO}_{2}$ sol to inactivate avian influenza virus (H9N2). The $\mathrm{TiO}_{2}$ photocatalytic film demonstrated a significant inactivation efficiency of $100 \%$ on H9N2 under the irradiation of $365 \mathrm{~nm}$ UV light. In addition, by increasing the UV intensity, extending the UV irradiation time and reducing the amount of virus, the inactivation efficiency of the $\mathrm{TiO}_{2}$ photocatalytic film on H9N2 can be improved.

\section{Non-metallic Nanomaterials}

Most of the metal (oxide) nanomaterials that are proved to have great antiviral activity contain heavy metals (such as $\mathrm{Ag}$ and $\mathrm{Cu}$ ), whose toxicity may cause damage to human health or the environment (Rai et al. 2016), no matter in water treatment or air purification. Therefore, it is necessary to find new non-toxic antiviral materials. Studies have confirmed that low toxicity non-metallic nanomaterials (mainly nanocarbon materials) display good antiviral properties. These carbon-containing nanomaterials include fullerenes (Snow et al. 2014), carbon nanotubes (Jang et al. 2016), graphene-based materials (Sametband et al. 2014), graphitic carbon nitrides $\left(\mathrm{g}-\mathrm{C}_{3} \mathrm{~N}_{4}\right.$ ) (Zhang et al. 2018a). Similar to nano metals and metal oxides, the mechanism of virus inactivation by nanocarbon materials also depends on nanometer size effect, electrostatic adsorption, or photocatalytic oxidation.

Carbon nanotubes (CNTs) are one-dimensional tubular nanomaterials made of graphene sheets curled around a central axis. According to the number of cylinder layers, it can be categorized into single-wall carbon nanotubes (SWCNTs) and multi-wall carbon nanotubes (MWCNTs). Since carbon nanotubes (CNTs) have a high specific surface area, smooth surface and good adsorption performance (Az'hari et al. 2019), they have been applied to inactivate viruses in water (Brady-Estévez et al. 2010b). It was also found that the trapping effect of the nanotube bundles in the carbon nanotube layer, the puncture effect on viruses, and the electrostatic adsorption could effectively remove most viruses 
in contaminated water (Brady-Estévez et al. 2010a). Carbon nanotubes are also used in the field of anti-virus in air. Park and Hwang (2014) used aerodynamic deposition (EAD) technology to coat carbon fiber nanotubes on glass fiber air filter media at atmospheric pressure and room temperature to inactivate MS2 virus. Both aerosol counting method and the plaque counting method were used for virus aerosol filtration and anti-virus tests. Carbon nanotube filter had a better filtering effect on suspended bacteriophage MS2 than ordinary air filter, and the pressure drop was very small. By controlling the area density of the coating, the filtration efficiency in the maximum penetration particle size area $(100 \mathrm{~nm})$ can be increased to $33.3 \%$, and the anti-virus efficiency can reach $92 \%$. Therefore, carbon nanotube air filters can be used in indoor air purification systems, gas masks and other fields.

Graphene is a hexagonal two-dimensional carbon nanomaterial with a honeycomb lattice composed of $\mathrm{sp}^{2}$ hybrid carbon atoms. It was featured by large specific surface area, high conductivity and high charge mobility, leading to sufficient surface active sites, good adhesion to microorganisms and the efficient generation of light-induced electron/ hole separation pairs (Miao et al. 2019). In addition, as a two-dimensional material, graphene exhibits excellent surface dispersibility and can be used as a substrate for catalytic systems (Georgakilas et al. 2016). It has been used as a highly effective dopant and sensitizer for improving the photocatalytic performance of metal oxide semiconductors (Li et al. 2016a). Akhavan et al. (2012) prepared a graphenetungsten oxide composite film and applied it to inactivate viruses under visible light. Compared with tungsten oxide and graphene-tungsten oxide film without composite structure, the $\mathrm{W}-\mathrm{C}$ and $\mathrm{W}-\mathrm{O}-\mathrm{C}$ bonds in the composite structure improved the photocatalytic performance. The MS2 virus protein on the surface of the film was almost completely destroyed after irradiation at room temperature for $3 \mathrm{~h}$, and the RNA outflow increased sharply. After 20 measurement cycles, the RNA outflow of the composite film decreased by $10 \%$, indicating that its photocatalytic performance remained stable within $60 \mathrm{~h}$.

Graphene oxide (GO), as a derivative of graphene, is a flake after graphite is oxidized. The GO surface possesses carboxyl groups, hydroxyl groups, and epoxide groups. These oxygen-rich groups make GO easy to functionalize (Gong et al. 2016). In addition, GO's forbidden bandwidth of $2-4 \mathrm{eV}$ provides good photocatalytic performance. Furthermore, during the process of virus disinfection, the sharp edges of GO can destroy and inactivate virus protein shells. Ye et al. (2015) reported the broad-spectrum antiviral activity of GO against pseudorabies virus (PRV, DNA virus) and porcine epidemic diarrhea virus (PEDV, RNA virus). This study showed that at concentrations below cytotoxicity, GO can significantly inhibit PRV and PEDV infection. When GO was combined with non-ionic polymer PVP, it showed antiviral activity. However, when combined with cationic polymer PDDA, GO failed to exhibit antiviral activity. These experimental results indicate that the effective anti-viral activity of GO is attributed to the unique singlelayer nanosheet structure and sharp edges leading to virus damage, as well as electrostatic interaction with the virus through the negative charge on the surface. The mechanism is summarized in Fig. 3a. GO tablets can also be used as carriers and stabilizers. For example, it can prevent Ag-np agglomeration, achieving a size suitable for antiviral activity, and fix Ag to reduce its biological toxicity (de Faria et al. 2014). Chen et al. (2016) studied the antiviral activity of GO and $\mathrm{GO}$ with $\mathrm{Ag}$ nanoparticles ( $\mathrm{Go}-\mathrm{Ag}$ ) against coated feline coronavirus (FCoV) and non-coated infectious bursa disease virus (IBDV). Go-Ag inhibited $25 \%$ of FCoV infection and $23 \%$ of IBDV, while GO only inhibited $16 \%$ of FCoV infection and shows no antiviral activity against IBDV infection.

Graphene-based nanomaterials have an excellent thermal conductivity which endows them with light-to-heat conversion capabilities (Wang et al. 2018). Deokar et al. (2017) synthesized sulfonated magnetic nanoparticles with reduced graphene oxide (SMRGO) to capture and photothermally destroy herpes simplex virus type 1 (HSV-1). Graphene sheets were anchored uniformly in spherical magnetic nanoparticles (MNP) whose size ranged from 5 to $25 \mathrm{~nm}$. Under the irradiation of near-infrared light (NIR, $808 \mathrm{~nm}$, $7 \mathrm{~min}$ ), SMRGO showed excellent (99.99\%) photothermal antiviral activity. This antiviral effect may be due to high virus capture efficiency, unique sheet structure, high surface area, and excellent photothermal properties of graphene. In addition, the electrostatic interaction of MNP with HSV-1 virus particles seemed to play a crucial role in suppressing viral infections.

g- $\mathrm{C}_{3} \mathrm{~N}_{4}$ is a typical polymer semiconductor with a bandgap of $\sim 2.7 \mathrm{eV}$ and exhibits catalytic activity even under visible light with bandwidth up to $460 \mathrm{~nm}$ (Mishra et al. 2019). In addition, it also has the advantages of high physical and chemical stability, no biological toxicity and low preparation cost (Darkwah and Ao 2018). Li et al. (2016b) first discussed the ability of $\mathrm{g}-\mathrm{C}_{3} \mathrm{~N}_{4}$ to inactivate viruses under visible light. The MS2 virus was completely inactivated after $360 \mathrm{~min}$ of irradiation. This study also investigated the mechanism of virus inactivation (Fig. 3b): photogenerated electrons and their derived $\operatorname{ROS}\left(\cdot \mathrm{O}^{2-}\right)$ dominated the inactivation process. Photocatalytic oxidation damaged the virus surface protein, resulting in the leakage and rapid destruction of internal RNA. Subsequently, this group (Zhang et al. 2018b) optimized the light intensity, photocatalyst loading and reaction temperature of photocatalysis through response surface method, reducing the time for completely inactivating the virus to $240 \mathrm{~min}$.

In addition to the single $\mathrm{g}-\mathrm{C}_{3} \mathrm{~N}_{4}$ photocatalytic inactivation of viruses, there are also studies of combining g- $\mathrm{C}_{3} \mathrm{~N}_{4}$ 
Fig. 3 a Speculated antiviral mechanism of GO (Ye et al. 2015). b The proposed mechanism of viral inactivation by $\mathrm{g}-\mathrm{C}_{3} \mathrm{~N}_{4}$ under visible light irradiation (Li et al. 2016b)
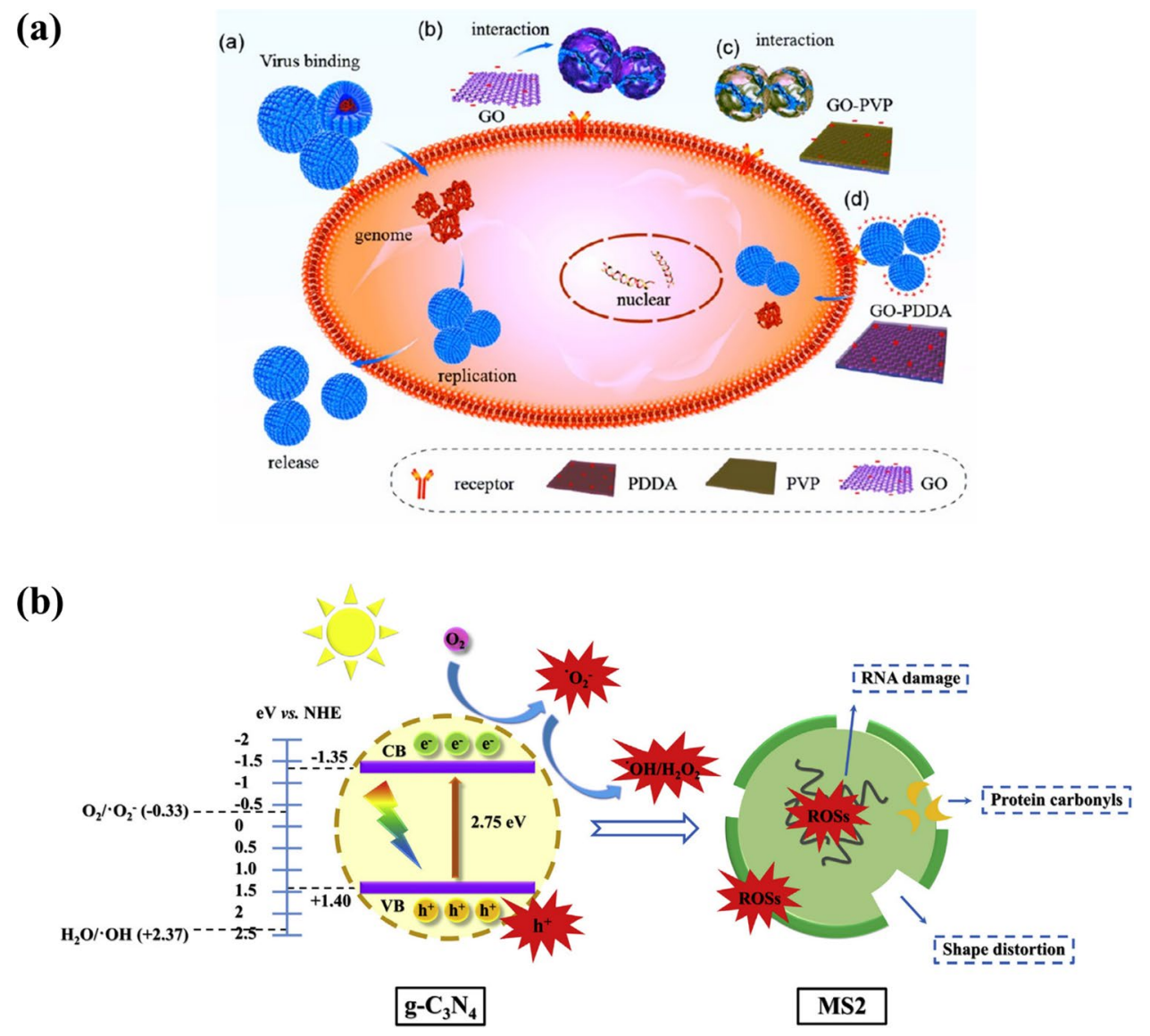

with semiconductors or constructing heterojunctions to improve the efficiency of photocatalysis. Cheng et al. (2018) synthesized $\mathrm{Ag}_{3} \mathrm{PO}_{4} / g-\mathrm{C}_{3} \mathrm{~N}_{4}$ ( $\mathrm{AgCN}$ ) composite materials and studied the photocatalytic inactivation ability of bacteriophage $\mathrm{f} 2$. The combination of $\mathrm{Ag}_{3} \mathrm{PO}_{4}$ and g- $\mathrm{C}_{3} \mathrm{~N}_{4}$ enhances the visible light response and reduces the carrier recombination rate. Under visible light irradiation, the photocatalytic inactivation efficiency of $\mathrm{AgCN}$ composite photocatalyst for bacteriophage f2 reached 6.5 $\log$ within $80 \mathrm{~min}$. Hole and $\cdot \mathrm{OH}$ radical play an important role in the process of photocatalytic disinfection. Zhang et al. (2019b) combined oxygen-doped graphite carbonitride microspheres $\left(\mathrm{O}-\mathrm{g}-\mathrm{C}_{3} \mathrm{~N}_{4}\right)$ with hydrothermal carbonization carbon (HTCC) to prepare a new type of metal-free heterojunction photocatalyst: $\mathrm{O}-\mathrm{g}-\mathrm{C}_{3} \mathrm{~N}_{4} / \mathrm{HTCC}$ microspheres. It showed strong absorption toward visible light and high killing efficiency against HAdV-2 virus under visible light irradiation. The mechanism of $\mathrm{O}-\mathrm{g}$ $\mathrm{C}_{3} \mathrm{~N}_{4}$ /HTCC enhancing virus-killing performance was revealed: the formation of Z-type heterojunctions enhances charge separation, fast charge transfer and reduces charge recombination, promoting the production of $\bullet \mathrm{OH}$, which was responsible for the rupture and deformation of the viral capsid.

\section{Perspective}

Nanomaterials have broad-spectrum antiviral capabilities and are expected to be used to block the aerosol transmission route of the virus. This review summarizes different types of antiviral nanomaterials, including metal nanomaterials, metal oxide nanomaterials with photocatalytic properties, and nonmetallic nanomaterials. The structural characteristics and chemical properties, the efficiency of inactivating viruses, the mechanism of inactivating viruses, and the virus purification application of antiviral nanomaterial are discussed. Although some progress has been made now, the development and application of antiviral nanomaterials still need to be worked on. Future studies can be focused on follows:

First, the scope of nano-antiviral materials should be expanded. It is known that photocatalytic nanomaterials can produce ROS to destroy the structure of viruses. However, their performance is greatly affected by the light source, which may increase their application cost. Further, the roomtemperature catalytic nanomaterials which can activate $\mathrm{O}_{2}$ to generate ROS without additional energy are promising candidates for air purification, deserving more attention. 
Second, the design and selection of antiviral nanomaterials should be optimized according to the application practice. When antiviral materials are applied to air purifiers, the high flow rate allows the virus to obtain higher kinetic energy. Therefore, the physical structure modification of nanomaterials should be strengthened to puncture or break viruses, and the electrostatic effect on the surface of nanomaterials should be increased to enhance the adsorption capabilities toward viruses. In addition, when antiviral nanomaterials are applied onto fabrics such as masks, carbon nanomaterials are the optimum choice due to their good biocompatibility. Moreover, liquid antiviral nanomaterials should be developed. Antiviral nano sols can be coated on indoor surfaces to continuously inactivate viruses, and antiviral nano sprays can be prepared to efficiently disinfect high-viral concentration environments.

Acknowledgements This work was supported by the National Natural Science Foundation of China, China (Grant nos. 51878644) and the National Key Research and Development Program of China, China (Grant nos. 2017YFC0212200 and 2016YFA0203000). This work was also partially supported by Strategic Priority Research Program of the Chinese Academy of Sciences, China (Grant nos. XDA23010300 and XDA23010000).

\section{Compliance with Ethical Standards}

Conflict of interest On behalf of all authors, the corresponding author states that there is no conflict of interest.

\section{References}

Ahmed SN, Haider W (2018) Heterogeneous photocatalysis and its potential applications in water and wastewater treatment: a review. Nanotechnology 29:342001. https://doi. org/10.1088/1361-6528/aac6ea

Akhavan O, Choobtashani M, Ghaderi E (2012) Protein degradation and RNA efflux of viruses photocatalyzed by graphene-tungsten oxide composite under visible light irradiation. J Phys Chem C 116:9653-9659. https://doi.org/10.1021/jp301707m

Armstrong AM, Sobsey MD, Casanova LM (2017) Disinfection of bacteriophage MS2 by copper in water. Appl Microbiol Biot 101:6891-6897. https://doi.org/10.1007/s00253-017-8419-x

Az'hari S, Mosaddeghi H, Ghayeb Y (2019) Molecular dynamics study of the interaction between RNA-binding domain of NS1 influenza A virus and various types of carbon nanotubes. Curr Sci 116:398-404. https://doi.org/10.18520/cs/v116/i3/398-404

Azimi P, Stephens B (2013) HVAC filtration for controlling infectious airborne disease transmission in indoor environments: predicting risk reductions and operational costs. Build Environ 70:150-160. https://doi.org/10.1016/j.buildenv.2013.08.025

Badireddy AR, Budarz JF, Chellam S, Wiesner MR (2012) Bacteriophage inactivation by UV-A illuminated fullerenes: role of nanoparticle-virus association and biological targets. Environ Sci Technol 46:5963-5970. https://doi.org/10.1021/es300340u

Belanger JM, Raviv Y, Viard M, de la Cruz MJ, Nagashima K, Blumenthal R (2011) Effects of UVA irradiation, aryl azides, and reactive oxygen species on the orthogonal inactivation of the human immunodeficiency virus (HIV-1). Virology 417:221-228. https://doi.org/10.1016/j.virol.2011.06.007

Bogdan J, Jackowska-Tracz A, Zarzynska J, Plawinska-Czarnak J (2015) Importance of $\mathrm{TiO}_{2} / \mathrm{UV}, \mathrm{ZnO} / \mathrm{UV}$ and $\mathrm{MgO} / \mathrm{UV}$ photocatalytic processes in the inactivation of infectious agents. Med Weter 71:472-479

Bogdanov A et al (2017) Nonactivated titanium-dioxide nanoparticles promote the growth of Chlamydia trachomatis and decrease the antimicrobial activity of silver nanoparticles. J Appl Microbiol 123:1335-1345. https://doi.org/10.1111/jam.13560

Brady-Estévez AS, Nguyen TH, Gutierrez L, Elimelech M (2010) Impact of solution chemistry on viral removal by a single-walled carbon nanotube filter. Water Res 44:3773-3780. https://doi. org/10.1016/j.watres.2010.04.023

Brady-Estévez AS, Schnoor MH, Kang S, Elimelech M (2010) SWNT-MWNT hybrid filter attains high viral removal and bacterial inactivation. Langmuir 26:19153-19158. https://doi. org/10.1021/la103776y

Brienen NCJ, Timen A, Wallinga J, van Steenbergen JE, Teunis PFM (2010) The effect of mask use on the spread of influenza during a pandemic. Risk Anal 30:1210-1218. https://doi.org/10.11 11/j.1539-6924.2010.01428.x

Broglie JJ, Alston B, Yang C, Ma L, Adcock AF, Chen W, Yang LJ (2015) Antiviral activity of gold/copper sulfide core/shell nanoparticles against human norovirus virus-like particles. PLoS ONE 10:14. https://doi.org/10.1371/journal.pone.0141050

Brondani MA, Siqueira AR (2018) A critical review of protocols for conventional microwave oven use for denture disinfection. Community Dent Health 35:228-234. https://doi.org/10.1922/ CDH_4372Brondani07

Camara MD, Yen S, Kaspar HF, Kesarcodi-Watson A, King N, Jeffs AG, Tremblay LA (2017) Assessment of heat shock and laboratory virus challenges to selectively breed for ostreid herpesvirus 1 (OsHV-1) resistance in the Pacific oyster, Crassostrea gigas. Aquaculture 469:50-58. https://doi.org/10.1016/j.aquacultur e.2016.11.031

Carratala A, Shim H, Zhong QX, Bachmann V, Jensen JD, Kohn T (2017) Experimental adaptation of human echovirus 11 to ultraviolet radiation leads to resistance to disinfection and ribavirin. Virus Evol 3:11. https://doi.org/10.1093/ve/vex035

Chen Y-N, Hsueh Y-H, Hsieh C-T, Tzou D-Y, Chang P-L (2016) Antiviral activity of graphene-silver nanocomposites against nonenveloped and enveloped viruses. Int J Environ Res Pub Health 13:430-430. https://doi.org/10.3390/ijerph13040430

Cheng R, Shen L, Yu J-h, Xiang S-y, Zheng X (2018) Photocatalytic inactivation of bacteriophage $\mathrm{f} 2$ with $\mathrm{Ag}_{3} \mathrm{PO}_{4} / \mathrm{g}-\mathrm{C}_{3} \mathrm{~N}_{4}$ composite under visible light irradiation: performance and mechanism. Catalysts 8:406. https://doi.org/10.3390/catal8100406

Cui H, Jiang J, Gu W, Sun C, Wu D, Yang T, Yang G (2010) Photocatalytic inactivation efficiency of anatase nano- $\mathrm{TiO}_{2} \mathrm{Sol}$ on the H9N2 avian influenza virus. Photochem Photobiol 86:11351139. https://doi.org/10.1111/j.1751-1097.2010.00763.x

Daghrir R, Drogui P, Robert D (2013) Modified $\mathrm{TiO}_{2}$ for environmental photocatalytic applications: a review. Ind Eng Chem Res 52:3581-3599. https://doi.org/10.1021/ie303468t

Daikoku T et al (2015) Decomposition of organic chemicals in the air and inactivation of aerosol-associated influenza infectivity by photocatalysis. Aerosol Air Qual Res 15:1469-1484. https://doi. org/10.4209/aaqr.2014.10.0256

Darkwah WK, Ao Y (2018) Mini review on the structure and properties (photocatalysis), and preparation techniques of graphitic carbon nitride nano-based particle, and its applications. Nanoscale Res Lett 13:388. https://doi.org/10.1186/s11671-018-2702-3

de Faria AF, Martinez DST, Meira SMM, de Moraes ACM, Brandelli A, Filho AGS, Alves OL (2014) Anti-adhesion and antibacterial activity of silver nanoparticles supported on graphene 
oxide sheets. Colloid Surface B 113:115-124. https://doi. org/10.1016/j.colsurfb.2013.08.006

Deokar AR, Nagvenkar AP, Kalt I, Shani L, Yeshurun Y, Gedanken A, Sarid R (2017) Graphene-based "hot plate" for the capture and destruction of the herpes simplex virus type 1 . Bioconjugate Chem 28:1115-1122. https://doi.org/10.1021/acs.bioco njchem.7b00030

Dong H, Zeng G, Tang L, Fan C, Zhang C, He X, He Y (2015) An overview on limitations of $\mathrm{TiO}_{2}$-based particles for photocatalytic degradation of organic pollutants and the corresponding countermeasures. Water Res 79:128-146. https://doi. org/10.1016/j.watres.2015.04.038

Doss N, Carré G, Keller V, André P, Keller N (2018) Photocatalytic decontamination of airborne $\mathrm{T} 2$ bacteriophage viruses in a small-size $\mathrm{TiO}_{2} / \beta$-SiC alveolar foam LED reactor. Water Air Soil Poll 229:29. https://doi.org/10.1007/s11270-017-3676-y

Foster HA, Ditta IB, Varghese S, Steele A (2011) Photocatalytic disinfection using titanium dioxide: spectrum and mechanism of antimicrobial activity. Appl Microbiol Biot 90:1847-1868. https://doi.org/10.1007/s00253-011-3213-7

Fujimori Y et al (2012) Novel antiviral characteristics of nanosized copper(I) iodide particles showing inactivation activity against 2009 pandemic H1N1 influenza virus. Appl Environ Microbiol 78:951. https://doi.org/10.1128/AEM.06284-11

Gaikwad S et al (2013) Antiviral activity of mycosynthesized silver nanoparticles against herpes simplex virus and human parainfluenza virus type 3. Int J Nanomed 8:4303-4314. https://doi. org/10.2147/ijn.S50070

Galdiero S, Falanga A, Vitiello M, Cantisani M, Marra V, Galdiero M (2011) Silver nanoparticles as potential antiviral agents. Molecules 16:8894-8918. https://doi.org/10.3390/molecules1 6108894

Ge ZY, Yang LM, Xia JJ, Fu XH, Zhang YZ (2020) Possible aerosol transmission of COVID-19 and special precautions in dentistry. J Zhejiang Univ Sci B. https://doi.org/10.1631/jzus.B2010010

Georgakilas V, Tiwari JN, Kemp KC, Perman JA, Bourlinos AB, Kim KS, Zboril R (2016) Noncovalent functionalization of graphene and graphene oxide for energy materials, biosensing, catalytic, and biomedical applications. Chem Rev 116:54645519. https://doi.org/10.1021/acs.chemrev.5b00620

Giannakis S, Liu ST, Carratala A, Rtimi S, Amiri MT, Bensimon M, Pulgarin C (2017) Iron oxide-mediated semiconductor photocatalysis vs. heterogeneous photo-Fenton treatment of viruses in wastewater. Impact of the oxide particle size. J Hazard Mater 339:223-231. https://doi.org/10.1016/j.jhazmat.2017.06.037

Gong X, Liu G, Li Y, Yu DYW, Teoh WY (2016) Functionalizedgraphene composites: fabrication and applications in sustainable. Energy Environ Chem Mater 28:8082-8118. https://doi. org/10.1021/acs.chemmater.6b01447

Gupta R, Modak J (2020) Bacterial lysis via photocatalysis-a critical mechanistic review. ChemCatChem 12:2148-2170. https:// doi.org/10.1002/cctc. 201901831

Gupta S, Tripathi M (2011) A review of $\mathrm{TiO}_{2}$ nanoparticles. Chin Sci Bull 56:1639-1657. https://doi.org/10.1007/s1143 4-011-4476-1

Han J et al (2005) Efficient and quick inactivation of SARS coronavirus and other microbes exposed to the surfaces of some metal catalysts. Biomed Environ Sci 18:176-180. https://doi.org/10.1007/ s00430-004-0219-0

Horie $\mathrm{M}$ et al (2008) Inactivation and morphological changes of avian influenza virus by copper ions. Arch Virol 153:1467. https://doi. org/10.1007/s00705-008-0154-2

Hu X, Mu L, Wen J, Zhou Q (2012) Covalently synthesized graphene oxide-aptamer nanosheets for efficient visible-light photocatalysis of nucleic acids and proteins of viruses. Carbon 50:27722781. https://doi.org/10.1016/j.carbon.2012.02.038
Hu YM, Lian XT, Dong H (2020) On silver nano particles and silverbearing materials as virus and bacteria killing agents. Acta Metall Sin 56:633-641. https://doi.org/10.11900/0412.1961.2020.00061

Hudson JB, Sharma M, Petric M (2007) Inactivation of Norovirus by ozone gas in conditions relevant to healthcare. J Hosp Infect 66:40-45. https://doi.org/10.1016/j.jhin.2006.12.021

Ishiguro $\mathrm{H}$ et al (2011) Photocatalytic inactivation of bacteriophages by $\mathrm{TiO}_{2}$-coated glass plates under low-intensity, long-wavelength UV irradiation. Photochem Photobiol Sci 10:1825-1829. https:// doi.org/10.1039/c1pp05192j

Jang HS, Jeon SK, Ryu KS, Nahm SH (2016) Removal of virus and toxin using heatable multi-walled carbon nanotube web filters. AIP Adv 6:7. https://doi.org/10.1063/1.4942596

Joe YH, Woo K, Hwang J (2014) Fabrication of an anti-viral air filter with $\mathrm{SiO}_{2}-\mathrm{Ag}$ nanoparticles and performance evaluation in a continuous airflow condition. J Hazard Mater 280:356-363. https ://doi.org/10.1016/j.jhazmat.2014.08.013

Joe YH, Park DH, Hwang J (2016) Evaluation of Ag nanoparticle coated air filter against aerosolized virus: anti-viral efficiency with dust loading. J Hazard Mater 301:547-553. https://doi. org/10.1016/j.jhazmat.2015.09.017

Kim J, Jang J (2018) Inactivation of airborne viruses using vacuum ultraviolet photocatalysis for a flow-through indoor air purifier with short irradiation time. Aerosol Sci Tech 52:557-566. https ://doi.org/10.1080/02786826.2018.1431386

Kim JY, Lee C, Love DC, Sedlak DL, Yoon J, Nelson KL (2011) Inactivation of MS2 coliphage by ferrous ion and zero-valent iron nanoparticles. Environ Sci Technol 45:6978-6984. https://doi. org/10.1021/es201345y

Kozlova EA et al (2010) Inactivation and mineralization of aerosol deposited model pathogenic microorganisms over $\mathrm{TiO}_{2}$ and $\mathrm{Pt} / \mathrm{TiO}_{2}$. Environ Sci Technol 44:5121-5126. https://doi. org/10.1021/es100156p

Lara HH, Ayala-Nuñez NV, Ixtepan-Turrent L, Rodriguez-Padilla C (2010) Mode of antiviral action of silver nanoparticles aginst HIV-1. J Nanobiotechnol 8:1-10. https://doi. org/10.1186/1477-3155-8-1

Laxma Reddy PV, Kavitha B, Kumar Reddy PA, Kim K-H (2017) $\mathrm{TiO}_{2}$-based photocatalytic disinfection of microbes in aqueous media: a review. Environ Res 154:296-303. https://doi. org/10.1016/j.envres.2017.01.018

Li Q, Page MA, Mariñas BJ, Shang JK (2008) Treatment of coliphage MS2 with palladium-modified nitrogen-doped titanium oxide photocatalyst illuminated by visible light. Environ Sci Technol 42:6148-6153. https://doi.org/10.1021/es7026086

Li X, Yu JG, Wageh S, Al-Ghamdi AA, Xie J (2016) Graphene in photocatalysis: a review. Small 12:6640-6696. https://doi. org/10.1002/smll.201600382

Li Y, Zhang C, Shuai D, Naraginti S, Wang D, Zhang W (2016) Visible-light-driven photocatalytic inactivation of MS2 by metalfree $\mathrm{g}-\mathrm{C}_{3} \mathrm{~N}_{4}$ : virucidal performance and mechanism. Water Res 106:249-258. https://doi.org/10.1016/j.watres.2016.10.009

Liga MV, Bryant EL, Colvin VL, Li Q (2011) Virus inactivation by silver doped titanium dioxide nanoparticles for drinking water treatment. Water Res 45:535-544. https://doi.org/10.1016/j.watre s.2010.09.012

Lindsley WG et al (2016) Viable influenza A virus in airborne particles expelled during coughs versus exhalations influenza other. Respir Viruses 10:404-413. https://doi.org/10.1111/irv.12390

Linnes JC, Rudnick SN, Hunt GM, McDevitt JJ, Nardell EA (2014) Eggcrate UV: a whole ceiling upper-room ultraviolet germicidal irradiation system for air disinfection in occupied rooms. Indoor Air 24:116-124. https://doi.org/10.1111/ina.12063

Liu Y et al (2020) Aerodynamic characteristics and RNA concentration of SARS-CoV-2 aerosol in Wuhan Hospitals during COVID-19 outbreak. bioRxiv. https://doi.org/10.1101/2020.03.08.982637 
Lu L et al (2008) Silver nanoparticles inhibit hepatitis B virus replication. Antivir Ther 13:253-262. https://doi.org/10.1016/j.antiv iral.2007.08.009

Malaithao K, Kalambaheti T, Worakhunpiset S, Ramasoota P (2009) Evaluation of an electronic air filter for filtrating bacteria and viruses from indoor air. Se Asian J Trop Med 40:1113-1120. https://doi.org/10.1590/S0036-46652009000500011

Marambio-Jones C, Hoek EMV (2010) A review of the antibacterial effects of silver nanomaterials and potential implications for human health and the environment. J Nanopart Res 12:15311551. https://doi.org/10.1007/s11051-010-9900-y

Mazurkow JM, Yüzbasi NS, Domagala KW, Pfeiffer S, Kata D, Graule $\mathrm{T}$ (2020) Nano-sized copper (oxide) on alumina granules for water filtration: effect of copper oxidation state on virus removal performance. Environ Sci Technol 54:1214-1222. https://doi. org/10.1021/acs.est.9b05211

McNeil SE (2009) Nanomaterial safety bulletin of the atomic. Scientists 65:56-61. https://doi.org/10.2968/065001007

Miao H, Teng ZY, Wang CY, Chong H, Wang GX (2019) Recent progress in two-dimensional antimicrobial nanomaterials. Chem Eur J 25:929-944. https://doi.org/10.1002/chem.201801983

Mishra A, Mehta A, Basu S, Shetti NP, Reddy KR, Aminabhavi TM (2019) Graphitic carbon nitride $\left(\mathrm{g}-\mathrm{C}_{3} \mathrm{~N}_{4}\right)$-based metal-free photocatalysts for water splitting: a review. Carbon 149:693-721. https://doi.org/10.1016/j.carbon.2019.04.104

Moongraksathum B, Chien M-Y, Chen Y-W (2019) Antiviral and antibacterial effects of silver-doped $\mathrm{TiO}_{2}$ prepared by the peroxo sol-gel method. J Nanosci Nanotechnol 19:7356-7362. https:// doi.org/10.1166/jnn.2019.16615

Murray BK et al (2008) Virion disruption by ozone-mediated reactive oxygen species. J Virol Methods 153:74-77. https://doi. org/10.1016/j.jviromet.2008.06.004

Ong SWX, Tan YK, Chia PY, Lee TH, Ng OT, Wong MSY, Marimuthu K (2020) Air, surface environmental, and personal protective equipment contamination by severe acute respiratory syndrome coronavirus 2 (SARS-CoV-2) from a symptomatic patient. JAMA 323:1610-1612. https://doi.org/10.1001/jama.2020.3227Pandey

Pandey NK et al (2019) A facile method for the synthesis of copper-cysteamine nanoparticles and study of ROS production for cancer treatment. J Mater Chem B 7:6630-6642. https://doi. org/10.1039/c9tb01566c

Pant B, Park M (2019) Recent advances in $\mathrm{TiO}_{2}$ films prepared by sol-gel methods for photocatalytic degradation of organic pollutants and antibacterial activities. Coatings 9:613. https://doi. org/10.3390/coatings9100613

Park K-T, Hwang J (2014) Filtration and inactivation of aerosolized bacteriophage MS2 by a CNT air filter fabricated using electro-aerodynamic deposition. Carbon 75:401-410. https://doi. org/10.1016/j.carbon.2014.04.019

Pradeep P, Chulkyoon M (2016) Non-thermal plasmas (NTPs) for inactivation of viruses in abiotic environment. Res J Biotechnol 11:91-96

Rai M, Deshmukh SD, Ingle AP, Gupta IR, Galdiero M, Galdiero S (2016) Metal nanoparticles: the protective nanoshield against virus infection. Crit Rev Microbiol 42:46-56. https://doi. org/10.3109/1040841X.2013.879849

Sametband M, Kalt I, Gedanken A, Sarid R (2014) Herpes simplex virus type-1 attachment inhibition by functionalized graphene oxide. ACS Appl Mater Inter 6:1228-1235. https://doi. org/10.1021/am405040z

Shionoiri N, Sato T, Fujimori Y, Nakayama T, Nemoto M, Matsunaga $T$, Tanaka $T$ (2012) Investigation of the antiviral properties of copper iodide nanoparticles against feline calicivirus. J Biosci Bioeng 113:580-586. https://doi.org/10.1016/j.jbios c.2011.12.006
Sjogren JC, Sierka RA (1994) Inactivation of phage MS2 by iron-aided titanium dioxide photocatalysis. Appl Environ Microbiol 60:344

Snow S, Park K, Kim J (2014) Cationic fullerene aggregates with unprecedented virus photoinactivation efficiencies in water. Environ Sci Technol Lett 1:290-294. https://doi.org/10.1021/ ez5001269

Szekeres GP et al (2018) Copper-coated cellulose-based water filters for virus retention. Acs Omega 3:446-454. https://doi. org/10.1021/acsomega.7b01496

Sze-To GN, Yang Y, Kwan JKC, Yu SCT, Chao CYH (2014) Effects of surface material, ventilation, and human behavior on indirect contact transmission risk of respiratory infection. Risk Anal 34:818-830. https://doi.org/10.1111/risa.12144

Takehara $\mathrm{K}$ et al (2010) Inactivation of avian influenza virus HIM by photocatalyst under visible light irradiation. Virus Res 151:102103. https://doi.org/10.1016/j.virusres.2010.03.006

Tang JW, Li Y, Eames I, Chan PKS, Ridgway GL (2006) Factors involved in the aerosol transmission of infection and control of ventilation in healthcare premises. J Hosp Infect 64:100-114. https://doi.org/10.1016/j.jhin.2006.05.022

van Doremalen N et al (2020) Aerosol and surface stability of SARSCoV-2 as compared with SARS-CoV-1. New Engl J Med 382:1564-1567. https://doi.org/10.1056/NEJMc2004973

Venieri D, Gounaki I, Binas V, Zachopoulos A, Kiriakidis G, Mantzavinos D (2015) Inactivation of MS2 coliphage in sewage by solar photocatalysis using metal-doped $\mathrm{TiO}_{2}$. Appl Catal B-Environ 178:54-64. https://doi.org/10.1016/j.apcatb.2014.10.052

Wang J (2013) Preparation and characterization of the anti-virus and anti-bacteria composite air filter materials. Sci China Technol Sci 56:48-52. https://doi.org/10.1007/s11431-012-5069-1

Wang JL, Zhang GK, Zhang PY (2018) Graphene-assisted photothermal effect on promoting catalytic activity of layered $\mathrm{MnO}_{2}$ for gaseous formaldehyde oxidation. Appl Catal B-Environ 239:7785. https://doi.org/10.1016/j.apcatb.2018.08.008

Wigginton KR, Kohn T (2012) Virus disinfection mechanisms: the role of virus composition, structure, and function. Curr Opin Virol 2:84-89. https://doi.org/10.1016/j.coviro.2011.11.003

Wilson P, Zumla A (2019) Transmission and prevention of acute viral respiratory tract infections in hospitals. Curr Opin Pulm Med 25:220-224. https://doi.org/10.1097/mcp.0000000000000566

Wu Y, Yao MS (2014) In situ airborne virus inactivation by microwave irradiation. Chin Sci Bull 59:1438-1445. https://doi.org/10.1007/ s11434-014-0171-3

Xia T, Kleinheksel A, Lee EM, Qiao Z, Wigginton KR, Clack HL (2019) Inactivation of airborne viruses using a packed bed nonthermal plasma reactor. J Phys D Appl Phys 52:12. https://doi. org/10.1088/1361-6463/ab1466

Xiang DX, Chen Q, Pang L, Zheng CL (2011) Inhibitory effects of silver nanoparticles on H1N1 influenza A virus in vitro. $\mathrm{J}$ Virol Methods 178:137-142. https://doi.org/10.1016/j.jviro met.2011.09.003

Xu R, Liu X, Zhang P, Ma H, Liu G, Xia Z (2007) The photodestruction of virus in Nano- $\mathrm{TiO}_{2}$ suspension. J Wuhan Univ Technol 22:422-425. https://doi.org/10.1007/s11595-006-3422-6

Yamaguchi Y et al (2016) Different hollow and spherical $\mathrm{TiO}_{2}$ morphologies have distinct activities for the photocatalytic inactivation of chemical and biological agents. Photochem Photobiol Sci 15:988-994. https://doi.org/10.1039/c6pp00093b

Yan LZ, Chen MX, He H, Qu JH (2005) Bactericidal effect of $\mathrm{Al}_{2} \mathrm{O}_{3}$-supported Ag catalyst. Chin J Catal 26:1122-1126

Ye $\mathrm{S}$ et al (2015) Antiviral activity of graphene oxide: how sharp edged structure and charge matter. ACS Appl Mater Inter 7:2157121579. https://doi.org/10.1021/acsami.5b06876

Zan L, Fa W, Peng T, Gong Z-k (2007) Photocatalysis effect of nanometer $\mathrm{TiO}_{2}$ and $\mathrm{TiO}_{2}$-coated ceramic plate on Hepatitis B virus. J 
Photochem Photobiol B 86:165-169. https://doi.org/10.1016/j. jphotobiol.2006.09.002

Zhang C, Li Y, Shuai D, Shen Y, Xiong W, Wang L (2018) Graphitic carbon nitride $\left(\mathrm{g}-\mathrm{C}_{3} \mathrm{~N}_{4}\right)$-based photocatalysts for water disinfection and microbial control: a review. Chemosphere. https://doi. org/10.1016/j.chemosphere.2018.09.137

Zhang C, Li Y, Zhang W, Wang P, Wang C (2018) Metal-free virucidal effects induced by $\mathrm{g}-\mathrm{C}_{3} \mathrm{~N}_{4}$ under visible light irradiation: statistical analysis and parameter optimization. Chemosphere 195:551558. https://doi.org/10.1016/j.chemosphere.2017.12.122

Zhang C, Li Y, Shuai DM, Shen Y, Wang DW (2019) Progress and challenges in photocatalytic disinfection of waterborne Viruses: a review to fill current knowledge gaps. Chem Eng J 355:399-415. https://doi.org/10.1016/j.cej.2018.08.158
Zhang C, Zhang M, Li Y, Shuai D (2019) Visible-light-driven photocatalytic disinfection of human adenovirus by a novel heterostructure of oxygen-doped graphitic carbon nitride and hydrothermal carbonation carbon. Appl Catal B-Environ 248:11-21. https://doi.org/10.1016/j.apcatb.2019.02.009

Zheng X, Shen ZP, Cheng C, Shi L, Cheng R, Dong J (2017) Electrospinning $\mathrm{Cu}-\mathrm{TiO}_{2}$ nanofibers used for photocatalytic disinfection of bacteriophage $\mathrm{f}$ : preparation, optimization and characterization. RSC Adv 7:52172-52179. https://doi.org/10.1039/c7ra0 $7770 \mathrm{j}$

Zheng X, Shen Z-P, Cheng C, Shi L, Cheng R, Yuan D-H (2018) Photocatalytic disinfection performance in virus and virus/bacteria system by $\mathrm{Cu}-\mathrm{TiO}_{2}$ nanofibers under visible light. Environ Pollut 237:452-459. https://doi.org/10.1016/j.envpol.2018.02.074 